\title{
METODE HERMENEUTIKA DAN PERMASALAHANNYA DALAM PENAFSIRAN AL-QURAN
}

\author{
Taufik Mukmin \\ STAI Bumi Silampari Lubuklinggau \\ taufikmukmin@staibsllg.ac.id
}

\begin{tabular}{ll}
\hline & Abstrak \\
\hline Article History & Hermeneutics is a method or \\
Received : 30-01-2019 & philosophical theory to interpret \\
Revised : 31-01-2019 & symbols related to the text in order to \\
Accepted :01-02-2019 & know the meaning and meaning. it was \\
\hline Keywords : & first used in the study of the Koran in \\
Hermeneutic Method, & the 19th century AD by Islamic \\
the Problem & scholars, but many scholars \\
In Interpretation of & questioned it. This is because it can \\
al-Quran & doubt the authenticity and sanctity of \\
& the Koran. Besides that, hermeneutics \\
& has been used to interpret bible to find \\
& its truth value. The Qur'an serves \\
& every question and objection from its \\
& readers, who come from various \\
& cultural backgrounds and scientific \\
& disciplines. Because the scriptures \\
& cannot speak for themselves, they need \\
& understanding, reading, interpretation \\
& and repetition of reinterpretations that \\
& are generally carried out by experts in \\
& the same way. In addition, the distance \\
& between the birth of the text and the \\
period of interpretation is very long. & For this reason, a methodological \\
& "means" is needed to understand the \\
& text in question.
\end{tabular}

\section{Pendahuluan}

Secara keyakinan keagamaan terdapat perbedaan antara $\mathrm{Al}-$ Qur'an dan kitab-kitab suci lainnya. Menurut keyakinan umat Islam, Al-Qur'an, baik lafal maupun makna, adalah firman Allah yang 
didiktekan Jibril kepada Muhammad. Keyakinan ini tentu tidak mudah diterima oleh pemeluk agama lain. Di sini unsur keyakinan dan keimanan ikut berperan. Terlepas apakah memang demikian halnya ataukah tidak, yang pasti Al-Qur'an tertulis dalam bahasa Arab dan persoalan pencarian makna yang sebenarnya selalu muncul ketika teks klasik itu dibaca dan dipelajari oleh generasi berikutnya yang hidup berselang waktu dan tempat. Belum lagi mereka yang membaca Al-Qur'an melalui terjemahan. Bagaikan sang guru, AlQur'an selalu mengembara dan setia menjumpai murid-muridnya bahkan juga para lawan yang mengkritiknya yang tersebar di seluruh bumi. Dengan kekuatan yang ada pada dirinya sendiri, Al-Qur'an melayani setiap pertanyaan dan sanggahan pembacanya, yang datang dari berbagai latar belakang kultur dan disiplin keilmuan.

Karena kitab suci tidak mungkin berbicara sendiri, maka ia perlu pemahaman, pembacaan, penafsiran dan pengulangan penafsiran ulang yang secara umum dilakukan oleh ahli dalam bagama. Selain itu jarak antara masa kelahiran teks dan masa penafsiran amatlah panjang. Untuk itu diperlukan "sarana" metodologis untuk memahami teks yang dimaksud.

Metodologi tafsir yang digunakan tentu harus sesuai dengan tuntunan Rasulullah s.a.w, para sahabat, tabi'in, serta para ulama yang ternama. Dengan kata lain, merekalah rujukan utama kita. Ilmu pertama yang lahir di kalangan umat Islam adalah Ilmu Tafsir. Ia menjadi mungkin (possible) dan menjadi kenyataan karena sifat ilmiah struktur bahasa Arab. Tafsir, benar-benar tidak identik dengan hermeneutika Yunani, ataupun hermeneutika Kristen, dan juga tidak sama dengan ilmu interpretasi kitab suci dari kultur dan agama lain ( al-Attas, 1991:54). Ilmu tafsir al-Quran adalah penting karena ia benar-benar merupakan ilmu dasar yang diatasnya dibangun keseluruhan struktur, tujuan, pengartian pandangan dan kebudayaan agama Islam. Itulah sebabnya mengapa al-Imam al-Thabari (w.923H) menganggapnya sebagai yang terpenting dibanding dengan seluruh pengetahuan dan ilmu (Abu Ja'far Ibn Jarir al-Tabari.1987: 54) Ini adalah ilmu yang mengupas hal ihwal kitab suci al-Quran dari segi sejarah turunnya, sanadnya, adab/cara membacanya, lafadzlafadznya, arti-artinya, yang berhubungan dengan hukum-hakamnya dan hikmah-hikmahnya (al-Imam al-Suyuthi, 1982: 11).

Namun, akhir-akhir ini, kita - umat Islam - dikejutkan oleh berbagai serangan arus pemikiran liberal, baik yang dilakukan oleh 
orientalis maupun orang-orang Islam yang terpengaruh pemikiran Barat. Dalam ilmu tafsir, dimunculkanlah hermeneutika. Ilmu yang mula-mula diterapkan dalam menafsirkan Bible, dipaksakan untuk dapat diterapkan dalam mentafsirkan berbagai kitab suci, termasuk al-Quran. Kalangan yang kurang peka atau tidak jeli memang cenderung memandang enteng persoalan ini bahkan menganggapnya bukan persoalan sama sekali. Alasannya, ilmu itu netral. Namun, apakah benar demikian? Kecuali wahyu yang berasal dari Allah S.W.T. Boleh dikata, semua produk pemikiran manusia pada hakikatnya tidaklah netral dalam arti bebas dari kepentingan para perumusnya dan pra anggapan yang menyertainya. Hanya mereka yang na if menganggap ilmu pengetahuan itu bebas nilai. Aneka ragam ideologi dan produk pemikiran sesungguhnya akrab dengan berbagai pra andaian terpendam (tacit assumptions) dan kepentingan terselubung (hidden interests) (Syamsuddin, 2008: 176-177)

Empat puluh lima tahun yang lalu, tepatnya pada tahun 1973, Syed Muhammad Naquib al-Attas mengingatkan umat Islam mengenai ilmu pengetahuan yang sesugguhnya tidak bebas nilai: Kita harus mengetahui dan menyadari bahwa sebenarnya ilmu pengetahuan tidak bersifat netral, setiap kebudayaan memiliki pemahaman yang berbeda-beza meskipun diantaranya terdapat beberapa persamaan. Antara Islam dan kebudayaan Barat terbentang pemahaman yang berbeda mengenai ilmu, dan perbedaan itu begitu mendalam sehingga tidak bisa dipertemukan (Wan Mohd Nor Wan Daud, 2003: 115) Sehingga pada penghujung abad ke-20 perkembangan ilmu pengetahuan dan kemajuan sain teknologi yang memberikan wacana baru untuk mengkaji pemahaman yang terkandung dalam al-quran, meskipun berbagai metode yang telah ditawarkan oleh para ahli tafsir hingga saat ini belum menemukannya (Abd al-Qadir Muhammad Salih, (2003: 6). Diantara metode tersebut adalah hermeneutika. (Sudarto, 1996:85)

Hermeneutika adalah suatu metode atau teori filsafat untuk mentafsirkan simbol yang berkaitan dengan teks supaya diketahui arti dan maknanya. mula digunakan terhadap kajian al-Quran pada abad $19 \mathrm{M}$ oleh para sarjana islam, akan tetapi banyak kalangan ulama mempersoalkannya. Ini karena hal tersebut dapat meragukan keaslian dan kesucian al-Quran. Disamping itu juga, hermeneutik telah diguna pakai dalam menafsirkan bible bagi mencari nilai kebenarannya. (Nasr Hamid Abu Zayd, 2003:34). Namun hal ini bertolak belakang 
terhadap penggunaannya kepada al-Quran yang telah diakui keotentikannya. Fazlur Rahman membawa wacana Hermeneutik melalui konsep Doble Movement of Interpretation iaitu sebagai alternative dari konsep lama tentang Qat'i dan Zanni. (Fazlur Rahman, 1998:6) Muhammad Arkon membangun kritik terhadap pemikiran Islam (Critique de la raison Islamique). Hasan Hanafi mencanangkan kebangkitan umat (Masyru' Nahdhawi) melalui projek besarnya, menerusi buku beliau yang berjudul al-Turath wa alTajdid. (Mohammad Arkoun, 1987:5) `Abid al-Jabiri, Pemikir asal Maroco mencetuskan kritik terhadap pemikir Arab (Naqd al-`Aql al'Arabi). (Mohammad Abid al-jabiri, 2003:89) Nasr Hamid Abu Zayd membangunkan kritikan terhadap wacana agama (Naqd al-Khitab alDini).(Nasr Hamid Abu Zayd, 1994:1) Kemudian Muhammad Syahrur menawarkan telaah Kontemporari terhadap Pemahaman Teks al-Quran (Qiraah Mu`ashirah).(Muhammad Syahrur, 1990: 6), ia adalah seorang tokoh yang banyak menimbulkan polemik, beliau berasal dari damaskus, Syiria.Terdapat dikalangan ilmuan yang menolak ide-ide yang beliau susun, diantaranya: Prof. Dr. Muhammad Sa`id Ramadhan al-Buti dalam majalah Nahj Islam, berjudul al-Khalfiyat al-Yahudiyyah li Siar Qiraah Mu`ashirah, (Disember 1990), Dr. Syauqi Abu Khalil dalam tulisannya berjudul Taqatu at Khatirah fi Darb al-Qiraah al-Mu`ashirah, dalam majalah Nahj Islam (maret 1991). Namun ada juga dikalangan mereka yang kagum dengan pendapat-pendapat beliau dengan anggapan dapat memberikan semangat baru dalam dunia pemikiran islam, separti Sultan Qaboos Kerajaan oman, beliau memberikan tanggapan yang positif serta merekomenkan kepada para menterinya untuk membaca karya Muhammad Syahrur, begitu juga para sarjana non Muslim separti Wael B. Hallaq dan Dael F. Eickelman. (Ahmd Zaki Mubarak, 2010: 4)

\section{Pembahasan}

\section{Pengartian Hermeneutika dan Sejarahnya}

Menurut Bahasa

Hermeneutika Secara bahasa diambil dari istilah yunani hermeneuein berasal dari bahasa Greek (http://ms. Wikipedia.org/wiki Bahasa_Greek). Hermeneutikos, yang mengandung tiga dasar makna, pertama mengungkapkan, kedua 
menjelaskan dan ketiga menterjemahkan (Mamat S. Burhanuddin, 2006:57). Dari ketiga-tiga makna tersebut dapat diistilahkan dengan interpretasi (Wan Mohd Nor Wan Daod,1998:384), iaitu; Pengucapan lisan, penjelasan yang dapat diterima oleh akal dan penyalinan dari satu bahasa ke bahasa lain. Hermeneutika dikenal dalam bahasa Inggris dengan kata hermeneutic atau to interpret, iaitu menginterpretasikan, menafsirkan dan menterjemahkan. Sedangkan dalam bahasa Arab arti yang mendekati dengan kata hermeneutika adalah Tafsir, Takwil, Syarh dan Bayan (Muzairi, 2003:54). walaupun pada dasarnya terjemahan ini tidak ada kesamaan sekali. Secara susunan bahasa antara kata hermeneutika (hermeneutic) dengan hermenetika (hermeneutics) terdapat perbedaan makna, dimana hermeneutic adalah bentuk adjektif, yang menunjukkan kepada sifat yang terdapat dalam pentafsiran, sedangkan hermeneutics adalah kata noun (benda) yang mengandung arti ilmu pentafsiran, ilmu untuk mengetahui maksud yang terkandung dalam kata-kata dan ungkapan penulis atau pentafsiran khusus terhadap kitab suci. (Fakhruddin Faiz, 2003:20)

Dalam bukunya yang berjudul The New Hermeneutic James M. Robinson menjelaskan, tidak ada justifikasi penambahan huruf (a) dalam kata hermeneutika atau huruf (s) hermeneutics, karena hermeneutics adalah bentuk tunggal . Dalam bahasa moden lain, separti dalam ejaan bahasa jerman adalah (hermeneutic) dalam ejaan bahasa perancis adalah (hermenetique) dan begitu juga dalam ejaan bahasa latin iaitu (hermeneutica). Dari ulasan diatas dapat dipahami bahwa penambahan huruf (a) dalam hermeneutika atau (s) hermeneutics adalah suatu arah baru bagi teori hermeneutis yang dapat disebut dengan Hermeneutika baru (Richard E. Palmer, 1969:6). Boleh jadi asal kata hermeneutik adalah dari kata hermeneuein dan hermeneia, yang dihubungkan dengan tokoh mitologi Yunani bernama Hermes (Noah Webster, 1979: 851). Yang disebutkan sebagai utusan para dewa dan mengantarkan arwah orang mati kedunia bawah.

\section{Menurut Istilah}

Hermeneutika adalah suatu istilah baru yang bersifat akademik, untuk mentafsirkan maksud, pengartian dan tujuan suatu teks-teks kuno.Secara epistimologi sebenarnya hermeneutik memiliki makna yang luas dan berkembang bermula dari ilmu untuk memahami 
bahasa dan teks, ilmu memahami kitab suci, kemudian menjadi cabang dari ilmu filsafat. (Jame M. Robinson ,1964:1-3) Kemudian hermeneutika ini dikembangkan menjadi suatu metodologi yang khusus untuk menafsirkan bible yaitu kitab suci orang-orang kristen. Yang menjadi pertanyaan, kenapa mereka membangun metodologi demikian? Karena didalam bible mereka menghadapi masalah dengan teks-teks bible itu sendiri. Mereka tahu bahwa bible ini bukan ditulis oleh Nabi Isa, AS. yang dipercayai orang-orang nasrani sebagai Yesus dan bukan pula ditulis oleh murid-murid Nabi 'Isa 'alaihissalam, tetapi ditulis oleh orang-orang yang tidak pernah bertemu dengan Nabi Isa, AS.. Jadi kalau kita lihat bible new testament atau perjanjian baru, disana ada Injil Johanes, Injil Markus, Injil Mathius, Injil Lukas dan sebagainya. Mereka ini adalah orangorang yang tidak pernah bertemu dengan Nabi Isa, AS. tetapi mereka menulis tentang bible dan menceritakan tentang kisah hidup Nabi Isa, AS.

Namun al-Quran memiliki riwayat yang mutawatir, seluruh alQuran memiliki jalur periwayatan yang amat banyak. Sedangkan bible, selain riwayatnya (ahad) tunggal, dibawa oleh seorang saja, iaitu: Johanes, Markus, Lukas dan Mathius hanya meriwayatkan seorang diri juga riwayatnya mursal, sanad atau mata rantai periwayatannya terputus, karena mereka tidak pernah bertemu dengan Nabi Isa, AS. Secara langsung. (Lihat Majalah Respon, 2008) Maka dari itu hermeneutika berfokus kepada tiga segi, iaitu; teks, konteks dan kontekstual.

\section{Hermeneutika dalam pandangan Ilmuwan}

Beberapa ilmuwan mengartikan hermeneutika menurut sudut pandang mereka. Paul Recoeur (1913-2005) (Paul Ricoeur, 2006: 3 5) mengartikan hermeneutika dari cara kerjanya, iaitu: teori tentang bekerjanya pemahaman dalam mentafsirkan teks. Zygmunt Bauman (1925)http://en.Wikipedia.org/wiki/Zygmunt_Bauman\#Bauman.27s_ Postmodernity.) mengartikan hermeneutika sebagai upaya untuk menjelaskan dan menelusuri pesan dan pengartian dasar dari sebuah ucapan atau tulisan yang tidak jelas, remang-remang dan kontradiksi lalu menimbulkan kebingungan bagi pendengar dan pembaca. Carl Braathen memaknakan hermeneutika sebagai ilmu yang mencoba menggambarkan bagaimana sebuah kata atau satu kejadian dalam waktu dan budaya lampau dapat dimengerti dan menjadi bermakna 
secara eksistensi dalam situasi sekarang untuk diaplikasikan dalam pentafsiran. (Carl E. Braaten, 1952: 132) Richard E. palmer memaknakan hermeneutika sebagai proses menelaah isi dan maksud yang menjelaskan dari sebuah teks sehingga kepada maknanya yang palig dalam. (Richard E. Palmer, 1969:14 - 18) Menurut Van A. Harvey terdapat perbedaan antara hermeneutika dengan hermetik, Hermetik adalah merupakan pandangan falsafah yang diasosiasikan pada tulisan literature ilmiah di Yunani Hermes Trismegistus, yang berkembang diawal abad masihi, adapun hermeneutika adalah suatu disiplin intelektual yang berkaitan dengan hakikat dan syarat-syarat mentafsirkan ekspresi manusia. (Van E. Harvey: 486)

Dari pemaknaan diatas dapat dibuat kesimpulan bahwa hermeneutika adalah teori pemahaman yang berkaitan dengan interpretasi teks yang mengandung kaedah-kaedah yang diperlukan untuk menginterpretasikan dokumen-dokumen yang tertulis dan lambang di dalam suatu kebudayaan. Kemudian hermeneutika lambat laun mengalami perubahan persepsi dan model pemakaiannnya, mulai dari pengartian bahasa kepada pengartian istilah dan teologi lalu berkembang menjadi istilah falsafah. (Robert Audi, 1995: 323) Kemudian sekitar abad ke 19 digunakanlah hermeneutika ini sebagai metode untuk menginterpretasikan al-Quran, baik dari teks, konteks dan kontekstualisasi, yang dipelopori oleh beberapa sarjana barat dan disambut baik oleh sebahagian sarjana muslim.

Maka secara umum hermeneutika dapat dirangkum dalam tiga kelompok, iaitu : objektif, subjektif dan kelompok pembebasan. Kelompok okjeftif disokong oleh Friedrich Schleiermacher (1768 1834), Wilheim Dilthey (1833 - 1911) dan Emilio Betti (1890 1968). Sedangkan kelompok subjektif di sokong oleh para tokoh hermeneutika, diantaranya adalah Martin Heidegger (1889 - 1976) dan Hans Georg Gadamer (1900 - 2002), adapun kelompok pembebasan dikembangkan oleh para sarjana Muslim, diantara mereka ialah: Hasan Hanafi (1935), Farid Esack (1959) dan Nasr Hamid Abu Zayd (1943) (Ahmad Zaki Mubarak, 2010:. 26 -27)

\section{Sejarah Perkembangan Hermeneutika}

Hermeneutika sebenarnya merupakan topik lama, namun kini muncul kembali sebagai sesuatu yang baru dan menarik untuk dibincangkan, apalagi dengan berkembangnya ilmu-ilmu sastera, sejarah, filsafat dan pentafsiran teks. Hermeneutika seakan telah hadir 
kembali dari masa lalu dan kini memiliki peranan yang penting dalam kajian-kajian tersebut. (E. Sumaryono, 2002: 23) Untuk memahami substantive hermeneutika, seseorang tidak dapat lari dari perspektif sejarah, falsafah dan teologi karena ia telah dikembangkan dalam kedua-dua disiplin tersebut. Seterusnya, perkembangan pemikiran terhadap hermeneutik secara lambat laun akan merebak ke berbagai wilayah disiplin ilmu lainnya, termasuk juga pada disiplin sastera, tafsir al-Quran dan usul al-Fiqh. (Ahmad Zaki Mubarak, 2010: 31)

\section{Menurut Perspektif Barat}

Menurut perspektif para sarjana barat hermeneutika berawal sejak zaman Yunani kuno, iaitu dari masa Aristotle (384 - 322 SM), beliau telah memunculkan masalah ini dalam bukunya yang berjudul "Peri Hermeneias", dengan arti dalam bahasa latin De Interpretatione dan dalam bahasa Inggris diartikan dengan on The Interpretation. (E. Sumaryono, 2002: 24- 26), Kemudian buku tersebut telah diterjemahkan ke dalam bahasa Arab oleh al-Farabi dengan terjemahan Fi al-'Ibarah. (F.W Zimmerman, 1981: 1) Perkembangan berikutnya hermeneutika dipergunakan sebagai metode untuk mentafsirkan naskah-naskah sejarah kuno dan kitab suci. Diantara disiplin ilmu yang paling banyak menggunakan hermenetika adalah ilmu tafsir kitab suci, separti kitab Zabur, Taurat dan Injil. (Ugi Suharto, 2003: 24) Kemudian sejarah interpretasi teks mengalami perkembangan yang sangat pesat melalui tradisi pemikiran teologi, baik Yahudi maupun Kristian, iaitu sekitar abad 4 dan 5 M. (F. Budi Hardiman, 2003: 42) Seterusnya pada abad ke- 17 dan 18 hermeneutika berkembang secara luas dalam berbagai disiplin ilmu pengetahuan, banyak sarjana barat yang memberikan idea-idea yang berkaitan dengan hermeneutika, separti Friedrich Schleiermacher (1768 - 1834), Wilhelm Dilthey (1833 - 1911), dan Rudolf Karl Bultman (1884 - 1976).

Lalu pada abad 20, pembahasan tentang hermeneutika didunia barat mengalami pembahsan yang cukup ramai, karena perdebatannya lebih mengarah pada persoalan ontologi (sebuah cabang ilmu falsafah atau metafisika yang berkaitan dengan fitrah makhluk) dan epistemologi. Lompatan hermeneutika kontemporari tersebut di pelopori oleh para filosuf besar separti; Martin Heidegger (1889 - 1976), Paul Ricoerur (1913 - 2005) dan Hans George Gadamer (1900 - 2002). 


\section{Menurut Perspektif Sarjana Muslim}

Dalam khazanah Islam Istilah hermeneutika memang tidak diketemukan, namun al-Farabi (w.339H) pernah membahas mengenai istilah hermeneutika dari karya Aristotle yang berjudul Peri Hermeneias, begitu juga dengan Abu Ma`syar $(272 \mathrm{H})$ dalam kitab beliau yang berjudul al-Ulf fi Buyut al-Ibadah, beliau ada menyebutkan istilah yang mirip dengan hermeneutika iaitu Hirmis, Harmes, yang diartikan dengan al-Muthalath bi al-Hikmah (tiga rangkaian aliran pemikiran), yang dijumpai dalam filsafah Yunani. (Mamat S. Burhanuddin, 2006: 76-77) Secara substansi istilah hermeneutika mulai dikaji dalam ilmu keislaman secara mendalam oleh sarjana muslim pada abad 19 M. Diantaranya adalah: Hassan Hanafi, Fazlur Rahman, Muhammad Arkoun, Nasr Hamid Abu Zayd, Riffat Hassan, Aminah Wadud, Farid Esack dan lain-lain. (Ahmad Zaki Mubarok, 2010: 35-36) Mereka dikenal sebagai tokoh yang mempelopori teori hermeneutika untuk menjadi salah satu teori pentafsiran al-Quran dengan berhujjah bahwa tafsir klasik perlu dikaji kembali untuk diselaraskan dengan wacana dunia modern. (Muzairi, 2003: 60-63)

Memang istilah hermeneutik dalam sejarah keilmuan Islam khususnya Tafsir al-Quran klasik tidak ditemukan. Istilah tersebut menjadi popular ketika Islam berada dalam kemunduran. Meskipun demikian, menurut Farid Esack dalam buku beliau Quran: Liberation and Pluralism, praktik hermeneutika sebenarnya telah dilakukan oleh umat islam sejak sekian lama, khususnya ketika memahami al-Quran, meskipun demikian, hermeneutika tidak mendapat sambutan yang positif daripada umat islam tradisional karena hermeneutika membawa beberapa bentuk aplikasi yang bertentangan dengan pendirian para ilmuan Muslim konvensional. (Ahmad Zaki Mubarok, 2010: 38) Diantara implikasi tersebut adalah disebabkan hermeneutika akan memberikan implikasi terhadap perubahan hukum- hukum yang telah mapan, hal tersebut akan mengakibatkan perpecahan dikalangan umat Islam, separti yang terjadi terhadap umat kritian dimana mereka menggunakan teori hermeneutika untuk memahami Injil, sehingga mereka terbagi menjadi dua kelompok Protestan dan Katolik. Maka dari keterangan diatas dapat disimpulkan bahwa sejarah hermeneutika dalam ilmu Islam tidak ditemukan akan tetapi beberapa pembahasan hermeneutik dalam ilmu 
keislaman telah sedia ada, meskipun begitu, perkara yang membezakan antara hermeneutika dengan konsep tafsir adalah teori hermeneutika selalu mengkritik teks dan meragukan keasliannya, hal ini tidak selari dengan konsep tafsir al-Quran.

\section{Problematika Penerapan Hermeneutika sebagai Metode Ilmu Tafsir al-qur'an}

Diantara konsep-konsep yang menjadi panduan para tokoh hermeneutik dalam pentafsiran terhadap al-Quran adalah: Relativisme Tafsir, dekonstruksi syari'ah dan Menolak otoritas Mufassir. Sehingga sebagaimana ungkapan dari seorang hermeneutik terkenal timur tengah Muhammad Syahrur dalam bukunya Qiraah Mu`asiran akan terjadi pemahaman yang sangat menghancurkan sendi-sendi islam dari akarnya, diantaranya adalah: Pertama. Penafian tentang kata-kata yang ada sinonimnya dalam bahasa al-Quran (al-Taraduf). Kedua. Penafian mengenai konsep penurunan al-Quran (Inzal wa Tanzil) atau penafian kepada Asbab al-Nuzul. Ketiga. Mengenai kemukjizatan al-Quran (I jaz al-Quran) dan keempat. Mengenai dialektik dan pengetahuan (al-Jadaliyah wa al-Ma`rifah). (Lihat Mamat S. Burhanuddin, 2002:81)

\section{Penafian Sinonim Dalam Bahasa al-Quran.}

Menurut Muhammad Syahrur, bahwa pandangan yang mengatakan kalimat-kalimat al-quran memiliki makna yang sama atau mirip adalah keliru karena menurut beliau setiap kalimat dalam al-Quran memiliki makna yang spesifik atau lebih dari satu makna, hal itu sebagai bukti kemukjizatan al-quran yang releven di setiap ruang dan waktu. (Muhammad Syahrur, 1990: 96) Dari konsep tersebut timbullah pentafsiran baru terhadap istilah-istilah dalam alQuran yang berlandaskan penafian sinonim. Maka separti kata-kata al-kitab, al-Quran al-Dhikir, al-Furqan, Uluhiyyah, al-Risalah, alNubuwwah, Islam, Iman dan lain sebagainya masing-masing mempunyai makna tersendiri. (Ahmad Zaki Mubarok , 2010: 90) Maka pentafsiran semacam ini bertentangan dengan metode tahlili yang telah menjadi kesepakatan para ulama, hal tersebut dapat dibuktikan dengan bentuk penafsiran lafaz separti berikut:

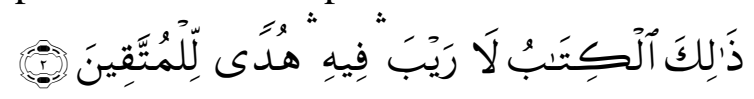


Kata لا شكّ فيه ditafsirkan oleh ulama tafsir dengan لا ريب فيه kena Rayba tidak sama maknanya dengan kata Syak maka penafsiran tersebut sebuah kekeliruan, begitu juga separti pentafsiran dalam ayat berikut:

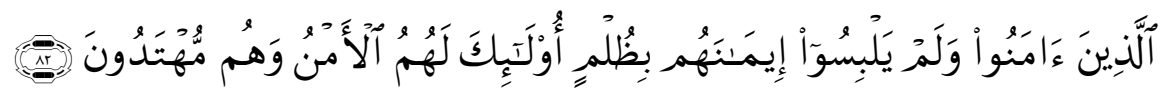

Kata al-Zulm pada ayat diatas ditafsirkan dengan al-Syirk, tafsiran tersebut daripada penjelasan Nabi s.a.w yang merujuk kepada ayat dalam surah Luqman, oleh sebab itu dengan penafian kepada sinonim dapat menafikan bentuk-bentuk tafsir yang telah dipraktekkan oleh nabi dan para sahabat dalam memahami al-Quran. (Abd Rahman, 2003: 3)

\section{Penafian Terhadap Asbab al-Nuzul al-Quran}

Al-Inzal adalah proses pemindahan maklumat yang diluar jangkauan akal manusia dari sesuatu yang abstrak menjadi dapat dipahami oleh manusia. Sedangkan al-Tanzil adalah proses pemindahan objek secara bentuk yang berlangsung diluar kesadaran manusia separti transformasi gelombang satelit. Lebih lanjut, Muhammad Syahrur menjelaskan mengenai proses penurunan alQuran dengan tiga istilah; al-Ja ${ }^{\prime}$, al-Inzal dan al-Tanzil. Al-Ja ${ }^{\top}$ adalah pengubahan wujud dari bentuk yang abstrak kepada bentuk yang dapat dipahami oleh manusia secara relative, ini bermakna alquran mengalami perubahan struktur eksistensi (Taghyir fi alSairurah). (Muhammad Syahrur, 1990: 152) Ia mencontohkan konsep al-Inzal dan al-Tanzil dengan tayangan TV yang menyiarkan pertandingan bola sepak secara langsung dari satu tempat kemudian dilihat oleh penonton yang berada di tempat yang lain.

\section{Kemukjizatan al-Quran}

Masih menurut Muhammad Syahrur, bahwa al-Quran mempunyai dua sisi kemukjizatan sastera dan ilmiah. Beliau menggunakan pendekatan deskriptif dan gramatis untuk kajian sastera al-Quran dan pendekatan histori untuk kajian ilmiah. (Muhammad Syahrur, 1990: 110)

\section{Dialektik dan pengetahuan dalam al-Quran}


Nashr Hamid Abu Zayd perpendapat dalam bukunya, "Hermeneutika Inklusif", permasalahan dasar yang diteliti hermeneutika adalah masalah penafsiran teks secara umum, baik berupa teks historis mahupun teks keagamaan. Oleh karenanya, yang ingin dipecahkan merupakan persoalan yang sedemikian banyak dan kompleks yang terdapat di sekitar watak dasar teks dan hubungannya dengan al-Turath di satu sisi, serta hubungan teks di sisi lain. Yang terpenting di antara sekian banyak persoalan di atas adalah bahwa hermeneutika mengkonsentrasikan diri pada hubungan antara orang yang menafsirkan (Mufassir) dengan teks. (Nashr Hamid Abu Zayd, 2004: 3) Ia berpendapat bahwa al-Quran adalah teks yang berupa bahasa (nasshun lughawiyyun). Peradaban Arab Islam tidak mungkin melupakan sentralisasi teks. Menurutnya, prinsip-prinsip, ilmu-ilmu dan juga kebudayaan Arab Islam itu tumbuh dan berdiri di atas teks. (Nashr Hamid Abu Zayd, 2004: 3)Namun demikian, teks tidak akan dapat berkesan kalau tidak ada campur tangan manusia. Artinya, teks tidak akan mampu mengembangkan peradaban dan keilmuan Arab Islam apabila tidak mendapatkan sentuhan dari pemikiran manusia. Dalam pandangan demikian, dengan kata lain agama sebagai teks tidak akan berfungsi apabila keberadaanya tidak dipikirkan manusia. Karenanya, ia berpendapat bahwa perkembangan Islam itu sangat tergantung kepada relasi dialektis antara manusia dengan dimensi realitasnya pada satu sisi, dan teks pada sisi yang lainnya. (Nashr Hamid Abu Zayd, 2004: 1) Di sini jelas terlihat Nashr Hamid Abu Zayd menganggap Islam dan al-Quran masih harus terus didialektikkan dan harus mengikuti perubahan zaman, bukan hanya dalam tataran praktis, namun juga dalam tataran konsep, termasuk konsep mengenai metode tafsir. Oleh karena itu kaum Ahlussunnah menyusun sumber-sumber utama pentafsiran al-Quran pada empat hal : penjelasan Rasulullah, sahabat, tabi'in, dan terakhir yaitu tafsir bahasa. (Nashr Hamid Abu Zayd, 2004: 35-36)

\section{Dampak Penerapan Hermeneutika Sebagai Metode al-Tafsir al- qur'an}

Hermeneutika, sebagai sebuah metode pentafsiran, tidak hanya memandang teks, tetapi hal yang tidak dapat ditinggalkannya adalah juga berusaha menyelami kandungan makna literalnya. Lebih dari itu, ia berusaha menggali makna dengan mempartimbangkan horizonhorizon yang melingkupi teks tersebut, baik horizon pengarang, 
horizon pembaca, mahupun horizon teks itu sendiri. Dengan kata lain, sebagai sebuah metode penafsiran, hermeneutika memerhatikan tiga hal sebagai komponen pokok dalam kegiatan penafsiran, yakni teks, konteks, dan kontektualisasi. (Kris Budiman, 2004:17) Jadi, ketika konsep teks al-Quran dibongkar, dan dilepaskan dari posisinya sebagai 'Kalam Allah' maka al-Quran akan diperlakukan sebagai 'teks bahasa' dan 'produk budaya' sehingga bisa dipahami melalui kajian historisitas, tanpa memperhatikan bagaimana Rasulullah s.a.w dan para sahabat beliau mengartikan atau mengaplikasikan makna ayat-ayat al-Quran dalam kehidupan mereka. Dengan pembongkaran al-Quran sebgaai 'Kalam Allah', maka barulah metode hermeneutika memungkinkan digunakan untuk memahami al-Quran. Metode ini memungkinkan pentafsiran al-Quran menjadi bias dan disesuaikan dengan tuntutan nilai-nilai budaya yang sedang dominan (Barat). (Adian Husaini dan Henri Salahuddin, 2004:36) Inilah dampak dari penerapan hermeneutika sebagai metode dalam pentafsiran al-Quran.

\section{Contoh Analisis Penafsiran ayat al-Qur`an menggunakan Metode Hermeneutika}

Masalah Pengharaman Khamar

Penafsiran terhadap ayat dalam surat al-Maidah ayat: 90 yang berbunyi:

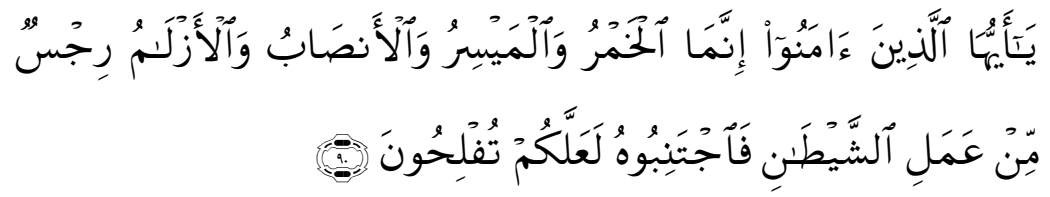

Maksudnya; Hai orang-orang yang beriman, Sesungguhnya (meminum) khamar, berjudi, (berkorban untuk) berhala, mengundi nasib dengan panah, adalah Termasuk perbuatan syaitan. Maka jauhilah perbuatan-perbuatan itu agar kamu mendapat keberuntungan. (QS. Al-Maidah: 90)

Ayat tersebut diatas menurut Nasr Abu Zay, secara konteks pada masa itu memang diharamkan, karena kondisi masyarakat Arab pada saat itu cuacanya sangat panas, tetapi dalam kondisi sekarang bahkan negara-negara yang memiliki cuaca dingin dan khamar itu dapat menghangatkan badan maka khamar tersebut hukumnya halal, 
maka seandainya seperti ini cara penafsirannya hanya melihat secara konteksnya akhirnya mereka juga akan mengatakan babi itu juga halal untuk dikonsumsi. (Adian Husaini, MA (VCD)

Analisis: Penetapan Pengharaman khamar disini bukan berarti karena manfa'at yang terkandung di dalamnya saja, namun lebih dari itu karena khamar ini dapat memabukkan dan termasuk ke dalam perbuatan yang keji.(M. Quraish Shihab, 2002: 192) Baik di tempat yang panas ataupun di tempat yang dingin. Rasulullah bersabda:

$$
\text { " كلّ مسكر خمر وكلّ خمر حرام " }
$$

"Setiap apa saja yang memabukkan adalah khamar, dan setiap khamar adalah haram".

Mengenai Pengharaman Babi

Allah berfirman dalam al-Quran surat al-Maidah ayat: 3 yang berbunyi:

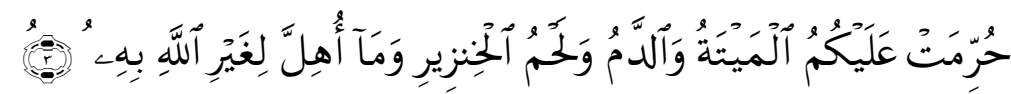

Maksudnya; diharamkan bagimu (memakan) bangkai, darah, daging babi, (daging hewan) yang disembelih atas nama selain Allah,

Maka secara konteks ayat tersebut diatas menurut tinjauan sosio hisstoris babi itu diharamkan karena di Arab jarang terdapat binatang itu jadi akan membuat seseorang susah untuk mendapatkannya dan akan membuat harganya pun menjai mahal, padahal jikalau dilihat dari konteks sekarang binatang tersebut merupakan salah satu binatang yang paling menguntungkan kalau dilihat dari segi perternakan sekalipun banyak kemuzaratan yang ditimbulkan oleh berbgai penyakit, namun secar kontekstualisasi itukan dapat diatasi yang penting konteksnya mendukung.

Analisis: Padahal jikalau dilihat lebih jauh dalam ayat ini tidak disebutkan siapa yang mengharamkan makanan-makanan yang disebut didalamnya. Ini menunjukkan hal itu bukan saja karena setiap muslim pasti mengetahui bahwa yang berwenang mengharamkan hanyalah Allah swt, tetapi juga untuk mengisyaratkan bahwaapa yang akan disebut berikut ini sedemikian buruk, sehingga siapapun pasti akan jijik. Lebih lanjut dalam ayat diatas hanya babi yang secara tegas disertakan kata daging ketika diuraikan keharamannya, 
walaupun yang lain juga pada hakikatnya yang diharamkan adalah dagingnya. Tahir bin `Asyur, penganut mazhab Malik, berpendapat bahwa penggandengan itu untuk mengisyaratkan bahwa yang haram adalah memakan babi, karena bila disebut kata daging yang terlintas didalam benak adalah memakannya. (M. Quraish Shihab, 2002: 192)

Mengenai Perkawinan Antar Agama

Dari hasil dekonstruksi dan interpretasi daripada teori hermeneutika maka firman Allah S.W.T yang terdapat dalam surat alMumtahanah ayat 10 yang berbunyi:

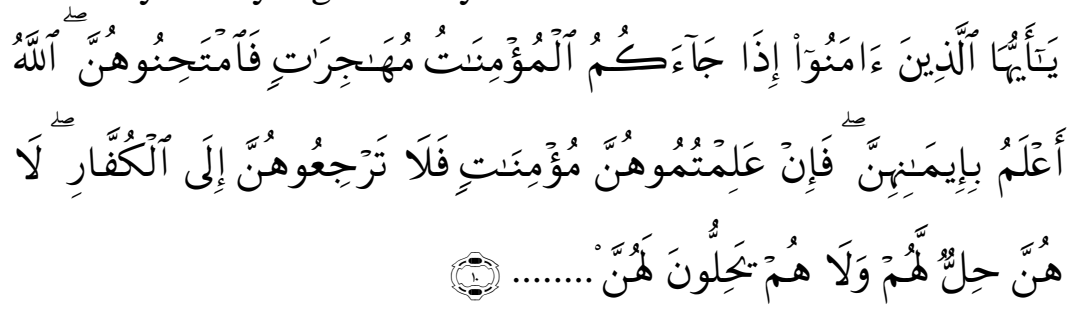

Maksudnya; "Hai orang-orang yang beriman, apabila datang berhijrah kepadamu perempuan-perempuan yang beriman, Maka hendaklah kamu uji (keimanan) mereka. Allah lebih mengetahui tentang keimanan mereka;maka jika kamu telah mengetahui bahwa mereka (benar-benar) beriman Maka janganlah kamu kembalikan mereka kepada (suami-suami mereka) orang-orang kafir. mereka tiada halal bagi orang-orang kafir itu dan orang-orang kafir itu tiada halal pula bagi mereka. dan berikanlah kepada (suami suami) mereka, mahar yang telah mereka bayar...(QS. al-Mumtahanah: 10)

Maka menurut Musdah Mulia yang ditulis dalam bukunya "Muslimah Reformis" bahwa dalam ayat tersebut diatas dalam konteks sekarang tidak berlaku lagi, karena jikalau kita melihat konteksnya pada zaman itu kondisi dunia dalam keadaan perang maka hal tersebut diharamkan, tetapi sekarang keadaan sudah aman dan bukan masa peperangan lagi maka berarti apabila perempuan Muslimah hendak menikah dengan laki-laki non Muslim itu bolehboleh saja. (Adian Husaini, MA (VCD)

Analisis: Dalam ayat diatas Allah swt menggunakan dua bentuk kalimat, yang pertama menggunakan bentuk Masdar(infinitive noun) 
dan yang kedua mudhari (present tense), penggunaan bentuk pertama untuk menyatakan bahwa sejak sekarang hal itu telah tidak halal, dan bentuk kedua bahwa itupun untuk masa yang akan datang tidak halal juga. (M. Quraish Shihab, 2002: 174)

\section{Simpulan}

Semua orang Islam pasti mengakui akan kemurnian dan kesucian ayat-ayat Allah yang ada dalam al-Qur'an, Namun ketika orang-orang Islam tidak mengenal al-Quran sebagai jantung Islam dan tidak bisa memahaminya dengan baik maka musuh Islam pun akan sangat mudah masuk ke dalam otak dan pikiran umat Islam melalui jantung kita sendiri, dan selanjutnya akan mengendalikan dan menguasai umat Islam itu sendiri.

Hermeneutika hanya akan menghancurkan Islam dari akarnya, karena ketika al-Quran telah diobrak-abrik maka segala sesuatu dalam Islam pun akan habis terkikis. Kajian al-Quran, terutamanya mengenai penafsirannya, tidak memerlukan hermeneutika. Kita patut khawatir, karena kaum muslimin akhir-akhir ini begitu bergairah mengimpor istilah hermeneutika untuk kajian al-Quran tanpa menyelidiki terlebih dahulu latar belakang istilah itu sendiri, yang memiliki cara pandang hidup yang berbeda dengan pandangan hidup Islam. Sebenarnya jika akan digunakan bahasa asing juga, maka istilah exegesis atau pun commentary atau penafsiran yang selama ini digunakan, itu sudah cukup memadai untuk memahami ayat-ayat alQuran. Akan tetapi sekarang exegesis atau commentary harus ditukar dengan hermeneutics.

Bisa kita bayangkan bagaimana jika metode hermeneutic of suspicion ini bila diterapkan secara liar untuk memaknai al-Quran alKarim. Sebelum membaca al-Quran kita mesti curiga terlebih dahulu terhadap isi al-Qur'an. Padahal sebelum membacanya kita diajar membaca ta'awudz :'Audzubillahi minasysyaithoonirrojiim', mohon perlindungan dari setan yang akan menyeret kepada kekeliruan dan kesalahan ketika membaca dan memahami al-Quran. Metode hermeneutika ini mengajar kita untuk menjadi setan sebelum membaca al-Quran, karena belum apa-apa, hati, pikiran dan logika telah dikondisikan untuk curiga akan kebenaran teks, kebenaran makna dan kebenaran ke-wahyuan al-Quran.

Betapa dahsyatnya kesesatan tafsir Hermeneutika ini. Dalam metodologi tafsir tidak pernah ada yang mempermasalahkan teks, 
karena Rasulullah SAW sendiri yang menafsirkan al-Quran. Jalur periwayatannya sudah jelas, mutawatir, para huffadz (penghafal alQuran) juga para Qurro' (ahli baca al-Quran) pun selalu menjaganya dalam sanubari mereka. Sepanjang sejarah manusia, tidak ada peradaban di dunia ini yang memiliki buku maupun kitab suci yang begitu hebat, yang dihafal dalam dada-dada jutaan pengikutnya. Sepakar-pakarnya atau seprofesor-profesornya ahli ekonomi tidak akan pernah menghafal bukunya Adam Smith "The Wealth of Nation", dan tidak akan tertarik menghafalkannya. Sebagai contoh sehebat-hebatnya seseorang dalam ilmu sosiologi ia tidak akan pernah tertarik untuk menghafal bukunya Max Weber. Seahli-ahlinya seseorang dia tidak mungkin berminat menghafal bukunya Karl Marx. Bahkan orang kristen sendiri tidak ada yang berminat untuk menghafal kitab suci mereka, walau betapa dia adalah pendeta tartinggi. Lain halnya dengan umat Islam. meskipun dia bukan orang Arab, namun selalu berupaya menjaga apa yang terkandung di antara dua lembar sampul kitab sucinya. Walaupun dia mungkin tidak mengerti setiap kosa kata Arab, tapi tahu dimana letak panjang pendeknya, tahu dimana harus berhenti, tahu dimana harus jelas dimana harus samar, tahu urutan-urutan ayat-ayatnya tanpa tertukar. Bahkan kita lihat, orang yang buta bisa lebih hafal dibanding orang yang bisa melihat. Buku/kitab mana lagi di dunia ini yang bisa mendekati kemukjizatannya dalam hal ketertarikan pengikutnya untuk menghafal. al-Quran telah dihafal secara massal dari sejak ayat demi ayatnya diturunkan. Jadi tidak mungkin terjadi kekeliruan dan penyimpangan. Keotentikan akan selalu terjaga. Bahkan satu huruf saja yang menyimpang dari al-Quran itu akan ketahuan, karena ilmu tentang huruf-huruf al-Quran pun ada dalam Islam. Wallahu A `lam. 


\section{DAFTAR PUSTAKA}

. 1981. Al Turath wa al-Tajdid, Kaherah: Daral-Tanwir li al-Tiba`ah; Kazuo Shimogaki (1997), Kiri Islam antara modernism dan postmodernisme: Telaah kritis pemikiran

Abid al-jabiri, Mohammad. 2003. Kritik Kontemporer atas filsafat Arab Islam, M. Nur Ichwan (terj.), Islamika: Takwin al-`Aqli al-`Arabi (1989), cet. IV. Beirut: Markaz Dirasat al-Wihdah alArabiyayah. Yogyakarta

Abu Zayd, Nashr Hamid . Mafhum al-Nass Dirasah fi Ulum alQur'an, (Kairo : al-Hay'ah al-Misriyah al-'Ammah li al-Kitab), 11. Dikutip dari tesis Arif Mansyuri, Konstruksi Tafsir Feminis (Studi Pemikiran Amina Wadud Atas Kesetaraan Jender dalam Al-Qur'an), IAIN Sunan Ampel Surabaya, 2006.

Abu Zayd, Nashr Hamid. 2004. Hermeneutika Inklusif-Mengatasi Peroblematika Bacaan dan Cara-Cara Pentakwilan atas Diskursus Keagamaan, ICIP: Jakarta.

Abu Zayd, Nashr. Hamid Mafhum al-Nas Dirasah fi Ulum alQUr'an, (Beirut : al-Markaz al-Thaqafiy al-Araby, 1994), hal 221-223. Dikutip dari Adian Husaini dan Henri Salahuddin, Studi Komparatif : Konsep Al-Qur'an Nashr Hamid Abu Zayd dan Mu'tazilah, Jurnal ISLAMIA, Tahun I No.2/Juni-Agustus 2004. 
Abu Zayd, Nasr Hamid. 1994. Naqd al-Khitab al-Dini. Kairo: Sina lial-Nasyr, cet. II, h. 1 - 3, Mafhum al-nass Dirasah fi al-Ulum al-Quran, (1994) cet II. al-Markaz al-Thaqafi al-`Arabi: Beurut.

Abu Zayd, Nasr Hamid. 2003. al-Quran Hermeneutika dan Kekuasaan, Dede Iswadi A.Rohman dan Ali Mursyid(terj.), RQis (Risearch for Quranic Studies): Bandung.

Adian Husaini, MA (VCD), Bahaya Hermeneutika Dalam Menafsirkan al-Quran, Lembaga Pengajian Perbandingan Agama, LP2A. Lihat insistnet.com.

al-Sayuti, Abd Rahman bin Aby Bakr Jalal al-Din. 2003. Tafsir alJalalain, Dar al-Khair: Beirut.

al-Suyuthi, al-Imam. 1982. Ilmu Tafsir (terjemahan) Bina Ilmu: Surabaya.

al-Tabari, Abu Ja'far Ibn Jarir. Jami' al-Bayan fi Ta'wil al-Qur'an, diterjemahkan dan diberi pengantar oleh J.Cooper (Oxford : OUP, 1987), selanjutnya sebagai Jami' al-Bayan, 1:8, dikutip dari Prof. Dr.Wan Mohd Nor Wan Daud, Tafsir dan Ta'wil Sebagai Metode Ilmiah, (Jurnal ISLAMIA, Tahun I No.1/Muharram $1425 \mathrm{H}$ ).

Arif, Syamsuddin. 2008. Orientalis \& Diabolisme Pemikiran-Bab Hermenutika dan Tafsir Al-Qur'an, Gema Insani Press: Jakarta.

Arkoun, Mohammad. 1987. al-Fikr al-Islami Qiraah Ilmiyah,Markaz al-Inma`al-Qaumi: Beirut.

Braaten, Carl E. 1952. New Direction in Theology, The Westminster Press: Philadelphia.

E. Palmer, Richard. 1969. Hermeneutics Interpretation Theory in Schleirmacher, Dilthey, Heideggerang gadamer. Northwestern University Press: Evanston.

Faiz, Fakhruddin. 2003. Hermeneutika Qurani antara teks, konteks dan kontekstuaitas, Qalam: Yogyakarta. 
Hanafi, Hassan. 1998. cet. III. Yokyakrta: LKiS, h. 68; A.H. Ridwan Reformasi Intelektual Islam. Yokyakata: Ittaqa press.

Hardiman, F. Budi. 2003. Melampaui Positivisme dan Modernitas (Diskursus Filosofis Tentang Metode Ilmiah dan Problem Modernitas), Kanisius: Yogyakarta.

http://en.wikipedia.org/wiki/Zygmunt_Bauman\#Bauman.27s_Postmo dernity.29 Oktober 2007.

http://ms. Wikipedia.org/wikiBahasa_Greek, pada 1 November 2007.

Husaini. Adian dan Henri Salahuddin, Studi Komparatif : Konsep AlQur'an Nashr Hamid Abu Zayd dan Mu'tazilah, Jurnal ISLAMIA, Tahun I No.2/Juni-Agustus 2004.

M. Robinson, Jame. 1964. The New Hermeneutic, New York.

Mubarak. Ahmd Zaki. 2010. Pendekatan Hermeneutk: Kajian terhadap Pemikiran Muhammad Syahrur dalam buku al-Kitab wa al-Quran Qiraah Mu ashirah (), jabatan al-Quran dan alHadith, Akademi Pengajian Islam, University Malaya - Kuala Lumpur.

Muzairi. 2003. Hermeneutik Dalam Pemikiran Islam, (Hermeneutik Mazhab Yogya), Islamika: Yokyakarta.

Muzairi. 2003. lihat juga Haidar Beagir. 2003. Hermeneutik dan teks Agama, Jurnal Tarjih, edisi ke-enam, Julai 2003,nMajlis Tarjih dan pengembangan pemikiran islam LPPI UMY: Yogyakarta.

Nor Wan Daod, Wan Mohd. 1998. The Educational Philosophy and practice of Sayyed Muhammad Naquib al-Attas: An exposition of the original concept of Islamization, ISTAC,: Kuala Lumpur.

Nor Wan Daud, Wan Mohd. 2003. Filsafat Praktik Pendidikan Syed M.Naquib Al-Attas, diterjemahkan dari The Educational Philosophy and Practice of Syed Muhammad Naquib Al-Attas, Mizan: Bandung. 
Nor Wan Daud, Wan Mohd. Tafsir dan Ta'wil Sebagai Metode Ilmiah, (Jurnal ISLAMIA, Tahun I No.1/Muharram 1425 H).

Rahman, Fazlur.1998. Islam and Modernity: Transformation of an Intelectual Tradition, The University of Chicago Press: Chicago London.

Ricoeur, Paul. 2006. (ia adalah seorang ahli filsafat), Hermeneutics and The Human sciences. Hermeneutika ilmu social Muhammad Syukri (terj.). Kreasi wacana:Yogyakarta.

Robert Audi. 1995. The Cambridge Dictionary of Philosophy, University Press: Cambridge.

S. Burhanuddin, Mamat. 2006. Hermeneutika al-Quran ala pesantren; Analisis terhadap Tafsir Marah Labid karya K.H. Nawawi al-Bantani,UII Press:Yogyakarta.

S. Burhanuddin, Mamat. 2006.lihat juga: M.T.H. Houtsma, A. J. Wensinck, (1987), Ensiclopedia of Islam, leiden: E.j. Brill Luzac, vol III.

Salih, Abd al-Qadir Muhammad. 2003. al-Tafsir wa al-Mufassirun fi al-Asr al-Hadith, Dar al-Ma`rifah: Beirut.

Shahrur, Muhammad. 2004. Prinsip-Prinsip Hermeneutika Al-Qur'an Kontemporer, bagian Pengantar Penerjemah, eLSAQ Press: Yogyakarta.

Sudarto. 1996. Metodelogi Penelitian Filsafah, P.T. Raja Grafindo Persada: Jakarta.

Suharto, Ugi. 2003. Jurnal Usuluddin University Malaya.

Sumaryono, E. 2002. Hermeneutik Sebuah Metode Filsafat, Penerbit Kanisius: Yogyakarta.

Syahrur, Muhammad. 1990. al-Kitab wa al-Quran Qiraah Mu`asirah. Cet. I, Damsyik. 
86 Taufik mukmin, Metode hermeneutika dan.....

Van E. Harvey, (t.t), Hermeneutic, dalam mercea Eliade, The Enyclopedia of Religions, New York: Macmillan Publishing Co. Vol 3.

Webster, Noah. 1979. Webster`s New Twentieth Century Dictionary, William Collins: USA.

Zimmerman, F.W. 1981. al-Farabi`s Commentary and Short Treatis on Arris totle`s De Interpretatione, The Oxforod University Press: London. 